\title{
Preliminary Inventory of the Phytobenthos and Aquatic Macroinvertebrates Communities Present in the Yulo Wetlands (Cundinamarca, Colombia)
} Jack Fran Armengot García Pérez

Programme of Environmental Engineering, University of Cundinamarca- Girardot, and Ave 19 N 24-209, Colombia

\begin{abstract}
This article is the first inventory of aquatic macroinvertebrates and the phytobenthic community present in the Yulo Wetland (Cundinamarca, Colombia) well as an approximation of the water quality of the wetland. Preliminarily recorded a total of 9 algal phytobenthic genres and 7 families of aquatic macroinvertebrates. In actuality, the Yulo wetland shows an advanced state of eutrophication and water is moderate pollution. However the Regional Corporation of Cundinamarca Auntonoma (CAR) with the Environmental Engineering Program is leading the development of environmental management plans to reduce the impact caused by the contamination of Bogota River, agricultural activities, livestock and urban planning.
\end{abstract}

Keywords: Phytobenthic community; Aquatic macroinvertebrates; Yulo wetland; CAR; Bogota river

\section{Introduction}

The Yulo wetland of present jurisdiction of Ricaurte, province of Magdalena high (Colombia). Limiting on the north by the Municipality of Agua de Dios, south Sumapaz and Magdalena rivers, west to the Rio Bogota and on the east by Nile town, represents the last wetland in the lower basin of Bogotá river (Figure 1). The wetland is present to the Cundinamarca department-Colombia. It features 101 hectare area and is in the floodplain landscape, to a height of $284 \mathrm{~m}$ with an average temperature of $27^{\circ} \mathrm{C}$. According to the Regional Autonomous Corporation of Cundinamarca (CAR), through the Agreement Number 39 (17 October 2006) defined " Yulo wetland as the water reserve because it is considered one of the few wetlands representative of tropical dry forest on the Bogotá river basin and providing shelter ecosystem" [1].

The phytobenthic community refers to the autotrophic organisms living associated with any bottom substrate in aquatic ecosystems, including cyanobacteria, microalgae, macro algae and macrophytes. The use of phytobenthos to assess the quality of water is a common practice in many countries and are indicator organisms of pressure given by eutrophication, salinity, acidification and other environmental stressors [2]. In the case of macroinvertebrate are organisms that are

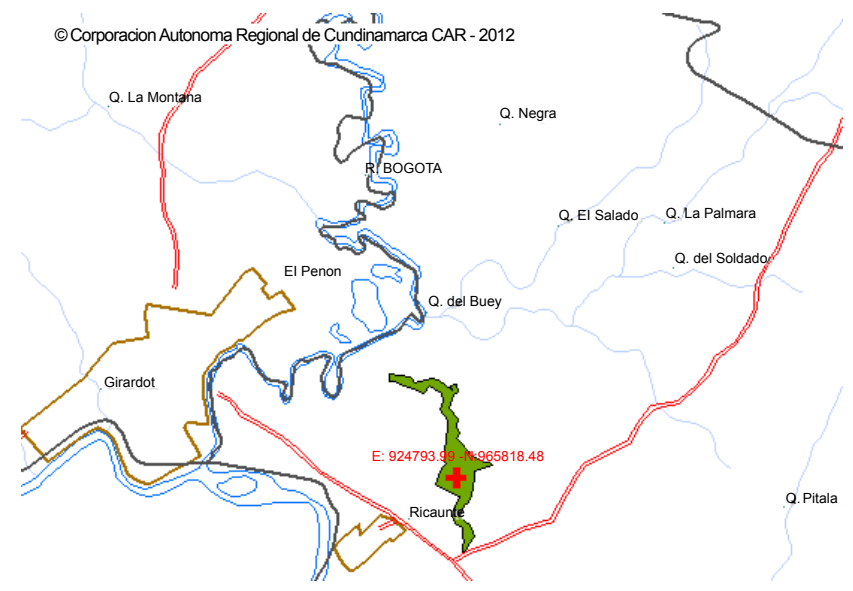

Figure 1: Location Yulo wetland (Cundinamarca, Colombia). large (macro) enough to be seen with the naked eye and lack a backbone (invertebrate). They inhabit all types of running waters, from fastflowing mountain streams to slow-moving muddy rivers. Examples of aquatic macroinvertebrates include insects in their larval or nymph form, crayfish, clams, snails, and worms. Most live part or most of their life cycle attached to submerged rocks, logs, and vegetation. Because aquatic macroinvertebrates are stationary and are sensitive to different degrees of pollution, changes in their abundance and variety vividly illustrate the impact pollution [3]

In 14 March 2012, the field practice was developed with students in environmental engineering from the Cundinamarca University In the wetland the Yulo were collected at three sites aquatic macroinvertebrate and phytobenthos samples (Table 1, Figure 2). Phytobenthos samples were collected in sterilized vials, taking samples phytobenthos surface and subsequently applying formaldehyde (4\%) and Lugol's iodine solution (10\%). Macroinvertebrates were collected through manual collection in stones and macrophytes. Phytobenthos community was analyzed using the Nygaard's algal index [4] and in the case of aquatic macroinvertebrates was used Biological Monitoring Working Party index [5].

\begin{tabular}{|l|l|l|l|}
\hline SITES & COORDENATES & ELEVATION M.A.S.L. & FEATURES OF HABITAT \\
\hline 1 & $\begin{array}{l}\text { N } 04^{\circ} 17^{\prime} 50^{\prime \prime} \\
\text { W } 74^{\circ} 45^{\prime} 59^{\prime \prime}\end{array}$ & 295 & $\begin{array}{l}\text { Macrophytes, Cyperaceae } \\
\text { Hidrocaritáceae }\end{array}$ \\
\hline 2 & $\begin{array}{l}\text { N } 04^{\circ} 17^{\prime} 35.8^{\prime \prime} \\
\text { W } 74^{\circ} 45^{\prime} 71.1^{\prime \prime}\end{array}$ & 289 & $\begin{array}{l}\text { Macrophytes, Cyperaceae } \\
\text { Hidrocaritáceae }\end{array}$ \\
\hline 3 & $\begin{array}{l}\text { N } 04^{\circ} 17^{\prime} 67.9^{\prime \prime} \\
\text { W } 74^{\circ} 45^{\prime} 60.3^{\prime \prime}\end{array}$ & 278 & $\begin{array}{l}\text { close wastewater treatment } \\
\text { plant }\end{array}$ \\
\hline
\end{tabular}

Table 1: Description of the three sites located in the Yulo Wetland (CundinamarcaColombia).

*Corresponding author: Geroncio C. Fajardo, Epidemiologist, Emergency Preparedness and Response Branch, Division of Preparedness and Emerging Infections, National Center for Emerging and Zoonotic Infectious Diseases, Centers for Disease Control and Prevention, 1600 Clifton Rd NE, MS C-18, Atlanta, GA 30333, USA, E-mail: geronciofajardo@yahoo.com

Received June 21, 2012; Published July 26, 2012

Citation: García Pérez JFA (2012) Preliminary Inventory of the Phytobenthos and Aquatic Macroinvertebrates Communities Present in the Yulo Wetlands (Cundinamarca, Colombia). 1: 158. doi:10.4172/scientificreports. 158

Copyright: ( 2012 García Pérez JFA. This is an open-access article distributed under the terms of the Creative Commons Attribution License, which permits unrestricted use, distribution, and reproduction in any medium, provided the original author and source are credited. 
Citation: García Pérez JFA (2012) Preliminary Inventory of the Phytobenthos and Aquatic Macroinvertebrates Communities Present in the Yulo Wetlands (Cundinamarca, Colombia). 1: 158. doi:10.4172/scientificreports.158

Page 2 of 2

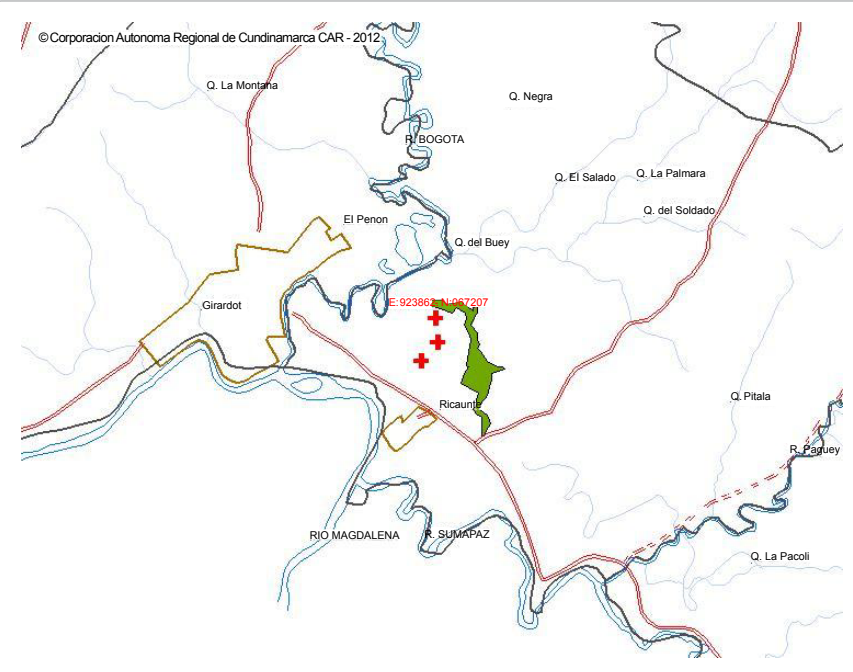

Figure 2: Collection sites and area of the water reservoir.

\begin{tabular}{|c|c|}
\hline Genres Phytobhentos & Aquatic Macroinvertebrates Families \\
\hline Oscillatoria sp & Aeshnidae \\
\hline Oscillatoria tenuis & Libellulidae \\
\hline Synechococcus & Coenagrionidae \\
\hline Ankistrodesmus sp & Hydropsychidae \\
\hline Ulothrix sp & Naucoridae \\
\hline Oedogonium $\mathrm{sp}$ & Paleomonidae \\
\hline Cyclotella $\mathrm{sp}$ & Lymnaeidae \\
\hline Nitzschia $\mathrm{sp}$ & \\
\hline Navicula $\mathrm{sp}$ & \\
\hline Closterium $\mathrm{sp}$ & \\
\hline
\end{tabular}

Table 2: Inventory of aquatic macroinvertebrates and phytobenthic community present in the Yulo wetland (Cundinamarca-Colombia).

The Hydrobiological Research Laboratory at the Cundinamarca University, phytobenthos and aquatic macroinvertebrates samples were analyzed and identified to the taxonomic level of families (macroinvertebrates) and genres (phytobenthos), using different keys and taxonomic notes: [5-9].

\section{Preliminary Evaluation}

The Nygaard's algal index resulted in a value of 5, why the Yulo wetland has preliminarily an advanced state of eutrophication. In the case of aquatic macroinvertebrates were 7 families, all sites showed a BMWP'Col index less than 48, indicating that water quality is moderately polluted (Table 2).

This preliminary registration of phytobenthos and aquatic macroinvertebrates associated with the wetland is a research experience for future environmental engineers, as well as opening a picture in the study of this wetland due to pressure and the incidence of Bogotá River, urbanization and different wastewater discharges that ecologically deteriorated this aquatic ecosystem.

\section{References}

1. CAR (2011) Humedales del Territorio CAR Colombia. Bogotá 76.

2. Cambra J, Luc E, Sabater S (2005) Protocolo de muestro y análisis para fitobentos (Microalgas bentónicas). Confederación Hidrográfica del Ebro-URS España, Cuenca Hidrografica del rio Ebro 46.

3. USEPA (1997) U.S Environmental Protection Agency. Field and laboratory methods for macroinvertebrate and habitat assessment of low gradient nontidal streams. USEPA, Mid-Atlantic Coastal Streams Workgroup. Environmental Services Division, Region 3. Wheeling WV49.

4. Nygaard G (1949) Hydrobiological studies in some ponds and lakes. Part II. The quotient hypothesis and some new or little known phytoplankton organisms. Kogl Danske Vidensk Selsk Biol Skr 7: 1-293.

5. Roldan Pérez G (2003) BIOINDICACION DE LA CALIDAD DEL AGUA EN COLOMBIA; Editorial Universidad Antioquia; Antioquia-Medellín 170.

6. Roldán G (1996) Guía para el estudio de los macroinvertebrados acuáticos del Departamento de Antioquia, Pama Editores Ltda. Bogotá, Colombia 217.

7. Fernández H, Domínguez E (2001) Guía para la determinación de los artrópodos bentónicos sudamericanos. Universidad Nacional de Tucumán Facultad de Ciencias Naturales y Instituto M. Lillo 282

8. Lowe RL, Laliberte GD (1996) Benthic stream algae distribution and structure págs 269-294. In HAUDER FR \& LAMBERTI, GA (eds.) Methods in stream ecology. Academic Press San Diego California.

9. Biggs BJF, Kilroy Cathy (1994) Stream Periphyton Monitoring Manual.NIWA Christchurch. New Zealand Ministry for the Environment 246. 